\title{
ARTICLE
}

\section{One-Pot Synthesis of Unsymmetrical Squaramides}

\author{
Juan V. Alegre-Requena, ${ }^{a}$ Eugenia Marqués-López ${ }^{a}$ and Raquel P. Herrera* ${ }^{a}$
}

The results concerning the first one-pot synthesis of unsymmetrical squaramides are reported. This straightforward procedure allows appealing and commonly used squaramide derivatives to be obtained with very good results. The methodology developed in this work saves energy, eliminates the purification steps for intermediate products, reduces costs and leads to better yields compared to those obtained through the traditional "stop-and-go" approach. Moreover, we have proved the efficiency of our process with the synthesis of three biologically active structures, improving the results of the previously reported stepwise syntheses. Interestingly, this simple and cheap method could attract the interest of pharmaceutical and chemical companies aiming to produce these active compounds at a large scale.

\section{Introduction}

The development of one-pot syntheses, in which at least two sequential transformations are performed in a single reaction flask, has gained much attention in the last decade, ${ }^{1}$ especially when these processes can afford chemicals and drug derivatives. ${ }^{1 \mathrm{c}}$ This growing interest is due to the increasing importance of sustainable chemistry, which involves saving resources and reducing waste. In stepwise syntheses, after each chemical transformation the process is stopped to purify and isolate the reaction intermediates previous to the subsequent reaction pathway. In this context, one-pot approaches could be the best option for reducing time, costs, resources and waste generation at an industrial scale, since these processes eliminate the purification of the intermediates between individual reaction steps, which is, in many cases, where more time and resources are wasted. Moreover, by reducing the number of synthetic steps and removing the intermediates' purification processes, it is possible to reduce the loss of material and, consequently, to increase the overall yield of the reaction sequence. ${ }^{2}$ Interestingly, from a biological and pharmaceutical point of view, using one-pot reactions is an attractive way to synthesise active compounds through the generation of large compound libraries, due to their ability to generate families of target products easily.

New strategies involving squaramides have attracted increasing interest due to their promising properties, becoming a fundamental motif in research. ${ }^{3}$ These compounds have unique properties that make them appealing for many different areas within chemistry, such as organic synthesis and catalysis and even medicine. In fact, since the pioneering work reported by Rawal and co-workers in $2008^{4}$ using squaramides as excellent hydrogen bond donor catalysts, this area has been experiencing an impressive growth in the organocatalysis field. ${ }^{3 a}$

Although squaramides have been the focus of many intensive studies, ${ }^{3}$ to the best of our knowledge, unsymmetrical squaramides have always been synthesised by using multi-step syntheses, which require purifying the reaction intermediates or changing the reaction media between synthetic steps. Therefore, the novel one-pot approach for synthesizing squaramides described in this work requires less time and resources and is cleaner than previously reported syntheses (Scheme 1).

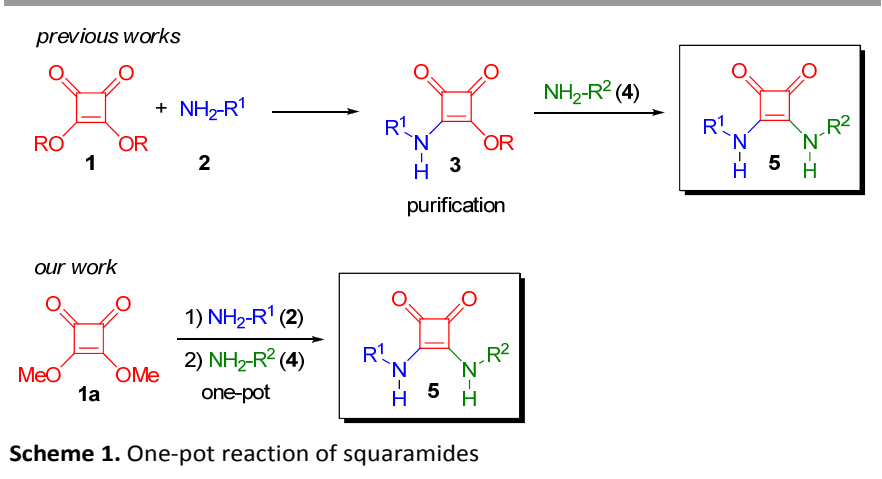


This work was intended to develop a more straightforward method for synthesizing squaramides that would enable this field to progress and evolve more quickly without the disadvantages of previous standard approaches. Moreover, we performed these syntheses without an excess of reactants, which proves these to be atom-economic processes. ${ }^{5}$ This not only saves resources, but generally also leads to obtaining pure final products after a simple filtration.

In this work, we report our appealing results concerning the first one-pot synthesis of a great number of squaramides (Scheme 1). ${ }^{6}$ Furthermore, in order to demonstrate the wide application of this protocol, the syntheses of three biologically active structures have been successfully accomplished (Figure $1)$.

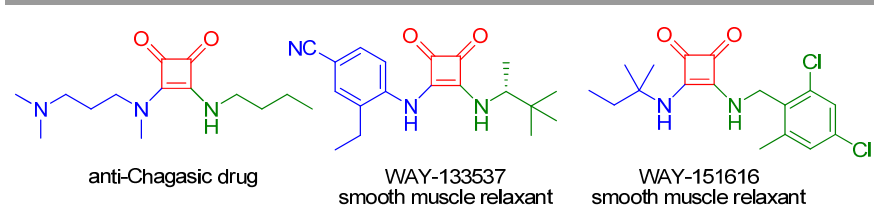

Figure 1. Target molecules synthesised

\section{Results and Discussion}

Focusing on the first step of the one-pot process and in order to check the viability of our idea, we performed an initial screening of solvents and concentration of the model reaction, shown in Table 1. We analysed which solvent presented the highest formation of product 3a, which is the first product obtained in the equivalent "stop-and-go" syntheses. Consequently, 3a is the first expected intermediate formed in the current one-pot approach and its formation is the limiting step of this reaction. The first amine addition is crucial in this method because an incomplete conversion of the initial reagents leads to lower yields of final squaramides 5. This decrease in the yield occurs because a smaller amount of intermediate $\mathbf{3}$ is available for the second amine addition, and the remaining squarate 1 could also react with the second amine. Thus, the generated amount of intermediate 3 limits the overall yield of the final squaramides in this one-pot procedure (Scheme 1).

Table 1. Screening of solvents in the model reaction.

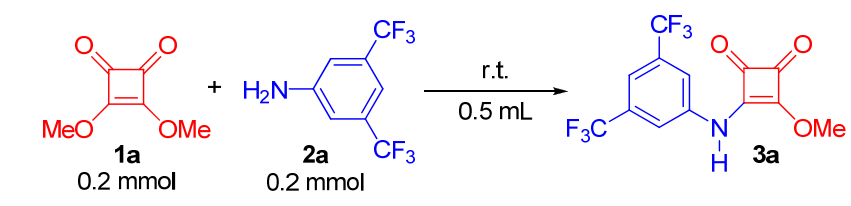

\begin{tabular}{llll}
\hline Entry & Solvent & $\begin{array}{l}\text { time } \\
(\mathrm{h})\end{array}$ & $\begin{array}{l}\text { yield } \\
(\%)^{\mathrm{a}}\end{array}$ \\
\hline 1 & $\mathrm{CHCl}_{3}$ & 24 & 47 \\
2 & $\mathrm{MeOH}$ & 24 & 59 \\
3 & EtOH & 24 & 53
\end{tabular}

4 5

$\mathrm{CH}_{3} \mathrm{CN}$

DMSO

24

DMF

24

1,4-Dioxane

24

Toluene

24

$\mathrm{MeOH}$

24

$10^{\mathrm{c}}$

$\mathrm{MeOH}$

85

n.r. ${ }^{b}$

n.r. ${ }^{b}$

n.r. ${ }^{b}$

n.r. ${ }^{b}$

69

$>95$

${ }^{a}$ Conversion calculated by ${ }^{1} \mathrm{H}-\mathrm{NMR}$ using dimethyl fumarate as the internal standard. ${ }^{b}$ No reaction. ${ }^{c}$ Reaction performed with $0.25 \mathrm{~mL}$ of $\mathrm{MeOH}$.

Among all the studied solvents, we found $\mathrm{MeOH}$ as the best choice for the synthesis of intermediate 3a (entry 2), whereas no reaction was observed with some polar solvents such as DMSO, DMF or 1,4-dioxane (entries 5-7). Non-polar solvents such as toluene also showed no reaction (entry 8). This was also observed by Luk and coworkers, who demonstrated that the addition of the second amine in squaramide synthesis was faster when hydrogen-bond donors were employed, concluding that solvents with a higher hydrogen-donor character led to better reactions rates. ${ }^{3 \mathrm{e}}$ In our work, this conclusion can be also stated since the reaction rates observed in the additions of the first amines depended on the hydrogen-bond donor acidities ${ }^{7}$ of the solvents and not on their dielectric constants. However, the use of pure water as the solvent was not effective since the formation of the final squaramides was low due to the high insolubility of intermediate 3a in this medium. Moreover, the hydrolysis of squarate $\mathbf{1 a}$ in water produced different byproducts as observed previously in other works. ${ }^{8}$ Increasing the concentration of the reaction had a pronounced positive effect on the yield. When using $0.25 \mathrm{~mL}$ of $\mathrm{MeOH}$, 3a was obtained in $69 \%$ yield, compared to the $59 \%$ yield obtained when $0.5 \mathrm{~mL}$ of $\mathrm{MeOH}$ was used (entry 9 vs entry 2). Additionally, testing the yield of the reaction at different times revealed that conversion of 3a was $>95 \%$ after 85 h (entry 10 ). This is of a great importance since $\mathrm{MeOH}$ has been considered one of the preferred green solvents. ${ }^{7}$

With these values in hand, we also explored the viability of the formation of intermediates $\mathbf{3 b}, \mathbf{c}, \mathbf{f}$ when using three other common anilines $(\mathbf{2} \mathbf{b}, \mathbf{c}, \mathbf{f})$, in order to prove if $\mathrm{MeOH}$ was also a useful solvent for other reagents (Scheme 2).

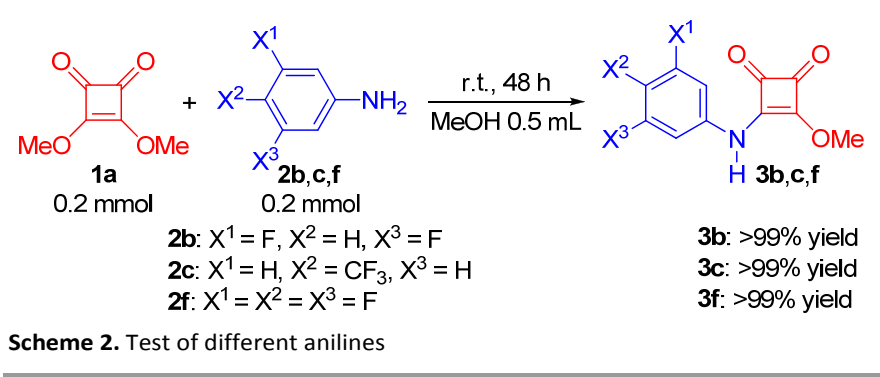


The screening of different anilines revealed that the process was also applicable to other substrates with excellent yields for the synthesis of intermediate squaramide monoamines $\mathbf{3 b}, \mathbf{c}, \mathbf{f}$ (Scheme 2).

After confirming the compatibility of this method with different anilines, the viability of the one-pot process was tested by incorporating the third reaction component (amine 4) in the reaction medium after the formation of intermediate 3 . A great number of anilines and amines were tested for the efficient formation of structures 5, which we are currently researching as promising organocatalysts for asymmetric catalysis (Table 2).
Among them there were 15 new squaramide structures (entries 1-16) and 11 structures that had previously been reported (entries 17-29). In our one-pot procedure, first we added amine $\mathbf{2 a - i}$ in one portion into a solution of squarate $\mathbf{1 a}$ in $\mathrm{MeOH}$, and after a reaction time of $t_{1}$, we added the second amine 4a-l dissolved in $\mathrm{MeOH}$. After a time of $\mathrm{t}_{2}$, the reaction was stopped and purified. Generally, the final products were purified by filtration, although in a few cases, these products were purified by column chromatography. 

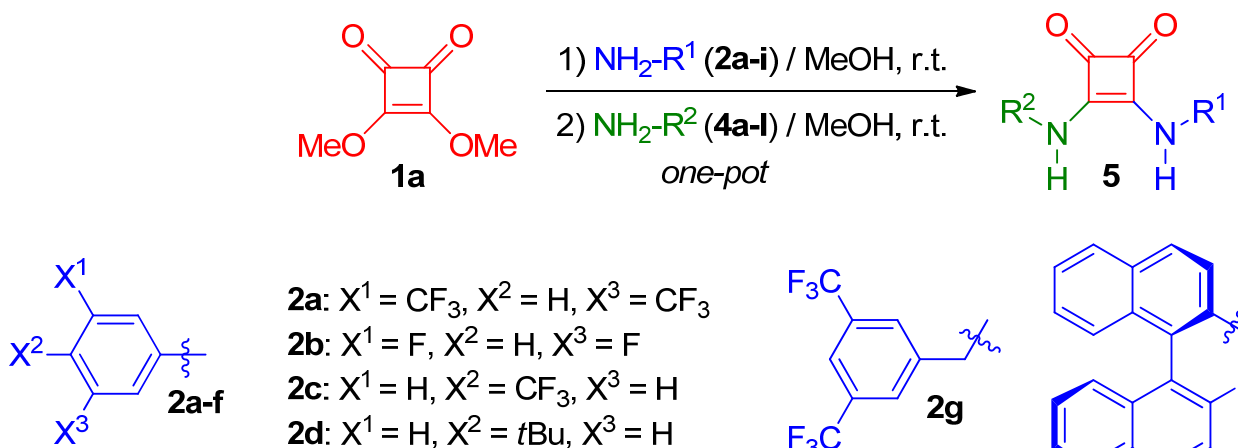

2a: $\mathrm{X}^{1}=\mathrm{CF}_{3}, \mathrm{X}^{2}=\mathrm{H}, \mathrm{X}^{3}=\mathrm{CF}_{3}$

2b: $X^{1}=F, X^{2}=H, X^{3}=F$

2c: $X^{1}=H, X^{2}=C_{3}, X^{3}=H$

2d: $X^{1}=H, X^{2}=t B u, X^{3}=H$

2e: $X^{1}=H, X^{2}=M e O, X^{3}=H$<smiles>CC(C)(C)Cc1cc(C(F)(F)F)cc(C(F)(F)F)c1</smiles><smiles>Cc1ccc2ccccc2c1-c1c(O)ccc2ccccc12</smiles><smiles>CC1CC2CC1CC(C)(C)C2</smiles>

2f: $X^{1}=X^{2}=X^{3}=F$<smiles>CCCCCC1CCCCC1NS(=O)(=O)c1ccc(C)cc1</smiles><smiles>C[C@H](c1ccccc1)[C@H](C)c1ccccc1</smiles><smiles>OC[C@H](Cl)Cc1ccccc1</smiles><smiles></smiles><smiles>CC(C)c1cccc2ccccc12</smiles>
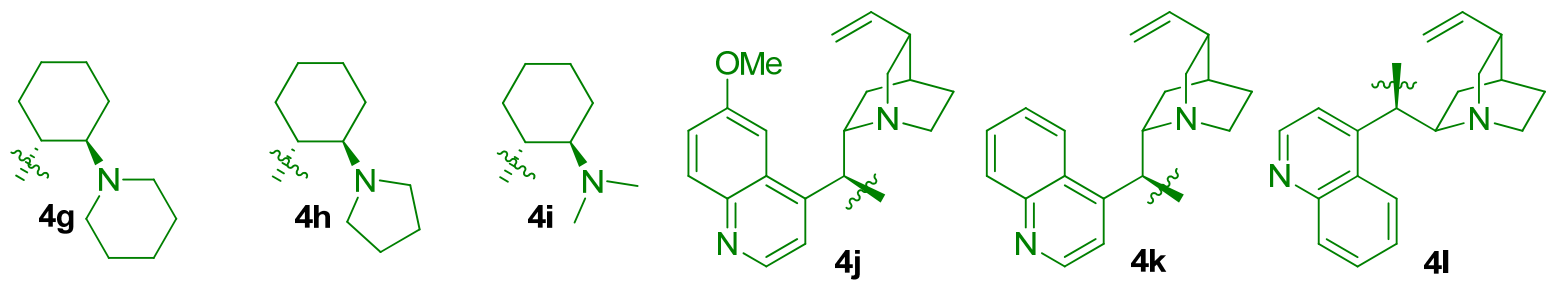

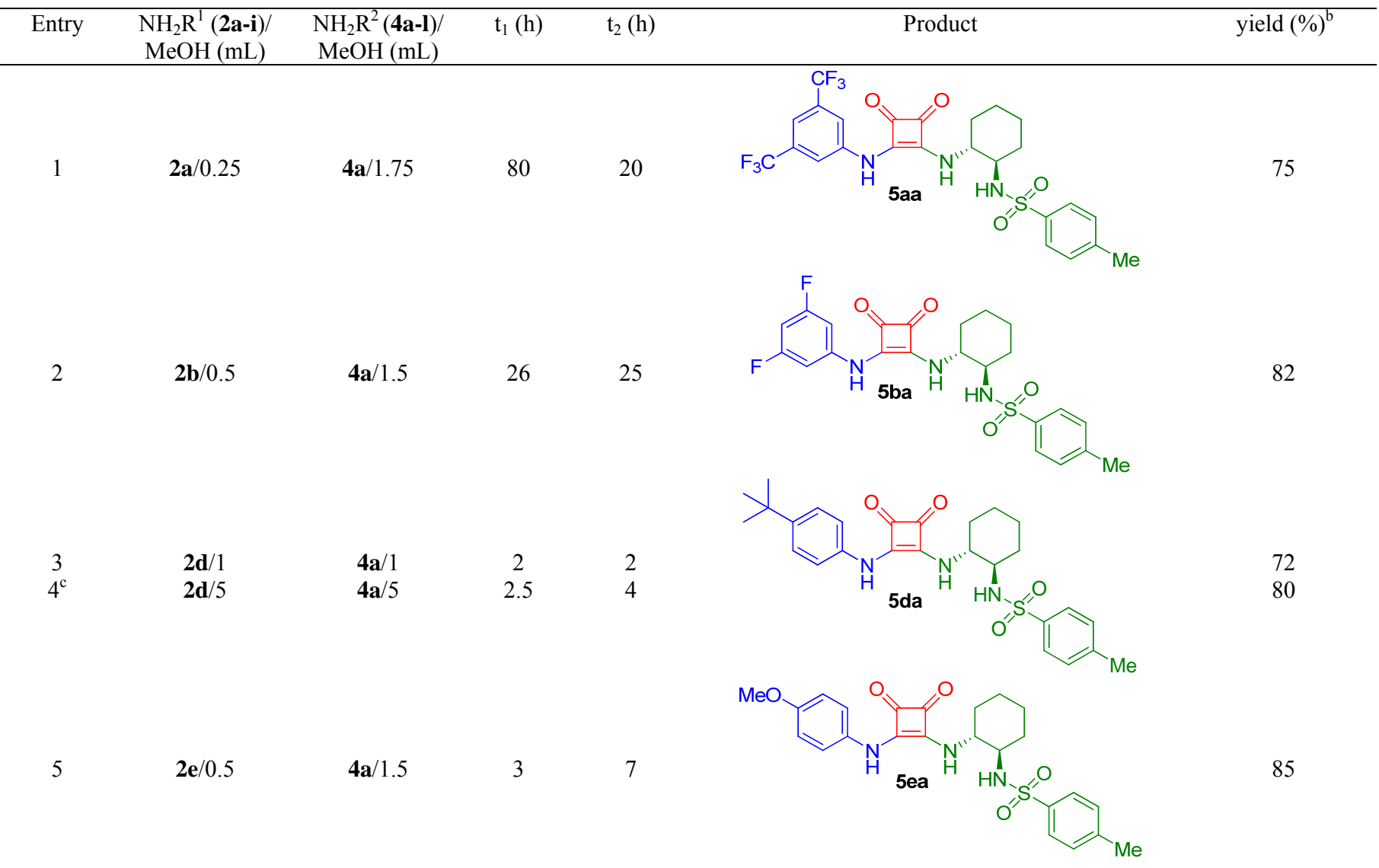




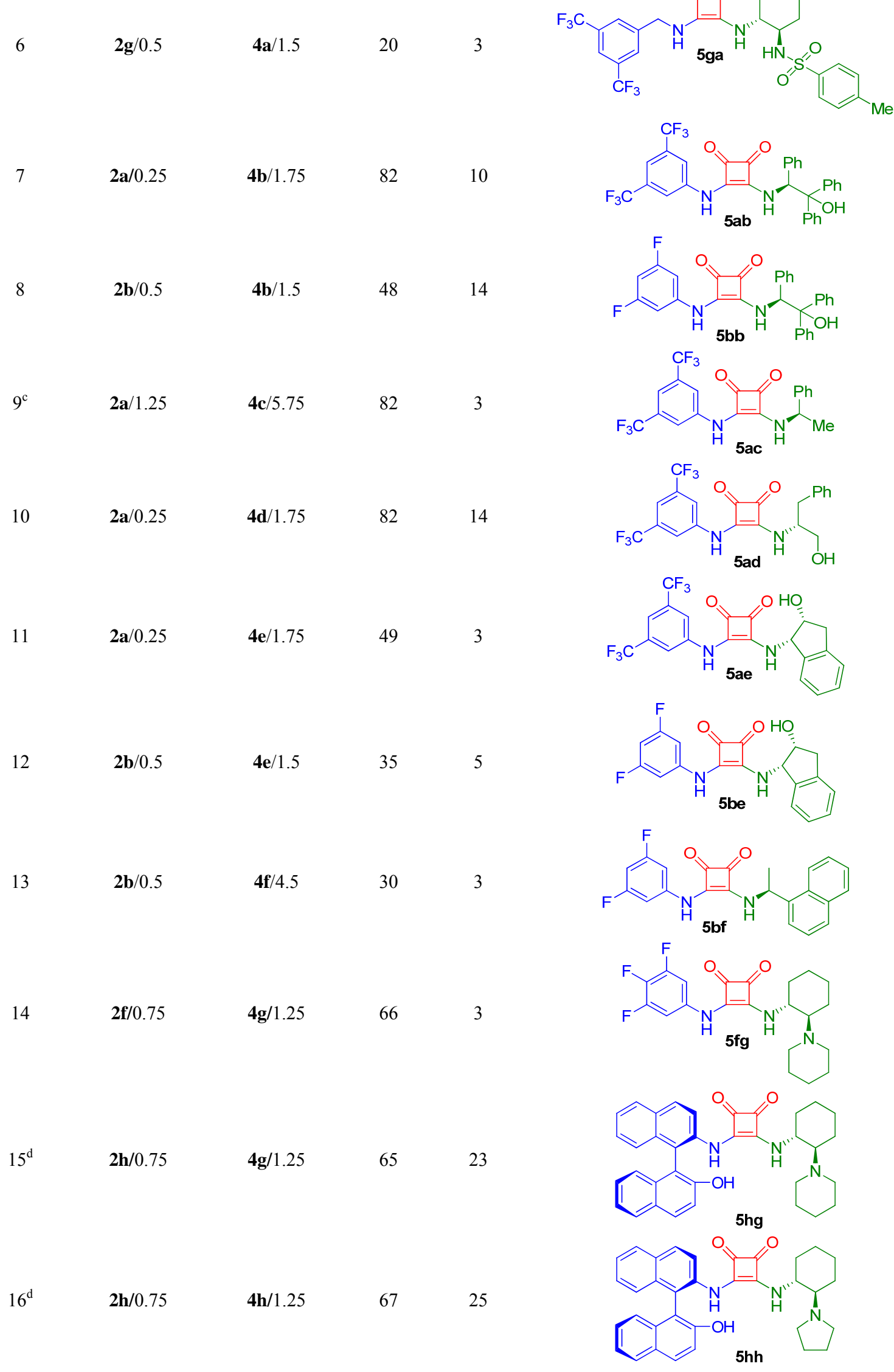


$4 \mathrm{~g} / 3.5$

77

2.5

$18^{\mathrm{g}}$

2c/1

4g/3

48

3

19

$2 \mathrm{a} / 0.25$

2a/0.5

$4 \mathbf{j} / 1.75$

$4 \mathrm{j} / 3.5$

72

76

48

$20^{\mathrm{g}}$

21

2c/0.5

$4 \mathbf{j} / 1.5$

48

48

$22^{\mathrm{g}}$

2g/1

$4 j / 3$

26

48

23

$2 \mathrm{a} / 0.25$

$4 \mathbf{k} / 1.75$

77

25

24

2c/0.5<smiles>CC(C)(C)c1c(Nc2cc(C(F)(F)F)cc(C(F)(F)F)c2)c(=O)c1=O</smiles><smiles>C1CCC(N2CCCCC2)CC1</smiles><smiles>CCCCCCCCCN(CC)C1CCCCC1[NH2+]c1c(Nc2ccc(C(F)(F)F)cc2)c(=O)c1=O</smiles><smiles>C=CC1CC2CCN1CC2C(Nc1c(Nc2cc(C(F)(F)F)cc(C(F)(F)F)c2)c(=O)c1=O)c1cnc2ccc(OC)cc2c1-c1ccccc1</smiles>

(49) ${ }^{12}$ $80^{\mathrm{h}}$
$(43)^{10}(65)^{9}$

$(58)^{10}(62)^{11}$

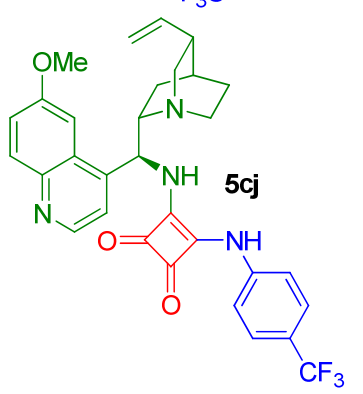

48 or $64^{\mathrm{i}}$ $(74)^{12}$

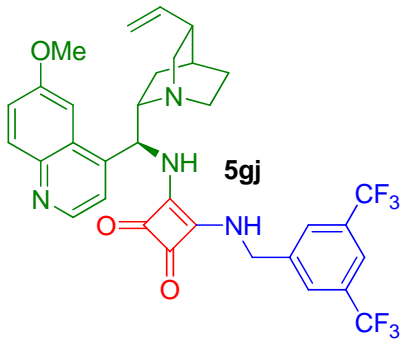

56 or 74

$(78)^{13}$

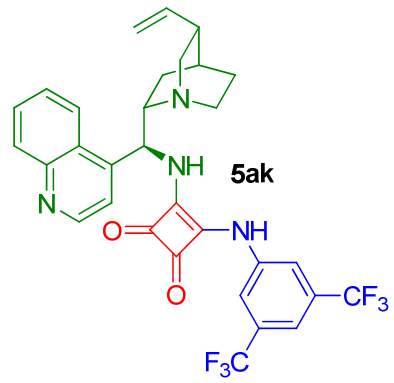

$67^{1}$

$(49)^{12}$

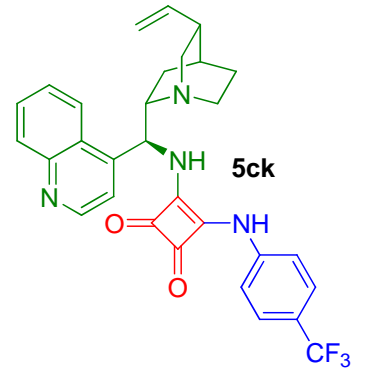

68 or $78^{\mathrm{i}}$

$(72)^{12}$ 


$\begin{array}{lcrll}25 & \mathbf{2 g} / 0.5 & \mathbf{4 l} / 1.5 & 22 & 48 \\ 26^{\mathrm{g}} & \mathbf{2 g} / 1 & \mathbf{4 l} / 3 & 26 & 48\end{array}$

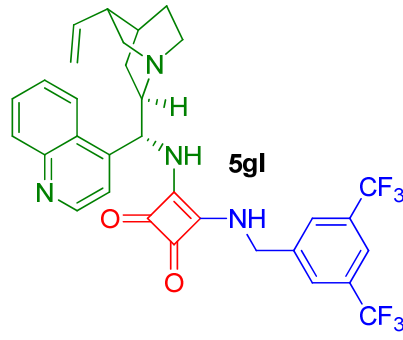<smiles>O=c1c(NCc2cc(C(F)(F)F)cc(C(F)(F)F)c2)c(NC2CCCCC2N2CCCCC2)c1=O</smiles><smiles>[15NH]C1=C(NC23CC4CC(CC(C4)C2)C3)C(=O)[C@@H]1C1CCCCC1N1CCCCC1</smiles><smiles>CN(C)C1CCCC[C@H]1Nc1c(Nc2cc(C(F)(F)F)cc(C(F)(F)F)c2)c(=O)c1=O</smiles>
$(30)^{15}$

53 or 67 60 $(29)^{10}(48)^{9}$

${ }^{a}$ Experimental conditions: To a mixture of squarate $1 \mathbf{a}(0.2 \mathrm{mmol})$ in $\mathrm{MeOH}(0.25-1 \mathrm{~mL})$, amine $2 \mathrm{a}-\mathbf{i}(0.2 \mathrm{mmol})$ was added in one portion at room temperature. After the reaction time $\mathrm{t}_{1}$, amine 4a-l $(0.2 \mathrm{mmol})$ was further added solved in $\mathrm{MeOH}(1-4.5 \mathrm{~mL})$. After $\mathrm{t}_{2}$, adduct 5 was filtrated under vacuum, placed at $-22{ }^{\circ} \mathrm{C}$ for 30 minutes and the solid was washed with cold $\mathrm{MeOH}(1 \mathrm{~mL}){ }^{b}$ Isolated yield. The results in parenthesis are the yields obtained by previous authors in the respective two-step syntheses. ${ }^{c}$ Reaction performed for 1 mmol of reagents. ${ }^{d}$ Reaction performed for 0.15 mmol of reagents. ${ }^{e}$ Purified by column chromatography $\left(\mathrm{SiO}_{2}\right.$, using Hex:EtOAc 6:4 to EtOAc:MeOH 9:1). ${ }^{f}$ Purified by column chromatography (SiO 2 , using EtOAc to EtOAc:MeOH $7: 3) .{ }^{g}$ Reaction performed for 0.4 mmol of reagents. ${ }^{h}$ Purified by column chromatography $\left(\mathrm{SiO}_{2}\right.$ treated with $\mathrm{Et}_{3} \mathrm{~N}, \mathrm{using} \mathrm{CH}_{2} \mathrm{Cl}_{2}$ to $\left.\mathrm{CH}_{2} \mathrm{Cl}_{2}: \mathrm{MeOH} 98: 2\right) .{ }^{i}$ Purified by column chromatography $\left(\mathrm{SiO}_{2}\right.$, using Hex:EtOAc 6:4 to EtOAc:MeOH 7:3).

In every reaction, final squaramides $\mathbf{5}$ were produced in moderate to very good yields (from $43 \%$ to $>95 \%$ yield). Unless otherwise indicated, the products were purified by a simple filtration of the final solid under vacuum conditions and washed with cold $\mathrm{MeOH}$. We were encouraged to observe that it was possible to slightly increase the yield of the process by performing the reactions on a larger scale (with 0.4 or $1 \mathrm{mmol}$ of reagents, entries 4,20 and 26). When performing these reactions at a larger scale, the loss of material reduced the overall yield less than at a small scale $(72 \%$ vs $80 \%$ in entries 3 and $4,45 \%$ vs $52 \%$ in entries 19 and 20 , and $43 \%$ vs $53 \%$ in entries 25 and 26). This is also interesting from an industrial point of view because even better yields could be expected at an industrial scale. The concentration of each reaction has been studied and optimised individually, based on the different insolubilities of the reagents and the final products. However, despite each reaction having its own optimization process, only slight modifications in the amounts of $\mathrm{MeOH}$ used in the reactions were necessary (Table 1). In most of the comparisons, the new one-pot procedure gave better results than the previous two-step approaches, showing an increase in yield of up to $23 \%$ compared to the highest values previously reported (entry 28). However, squaramides 5cj (entry 21) and 5gj (entry 22) were obtained in slightly lower yields than those previously reported in the "stop-and-go" procedures. In our case, the slightly lower yield could be attributed to the small scale at which the reactions were performed, but better results could be expected when these processes are scaled-up as we have already demonstrated for some examples.

Interestingly, the commercially available squaramide organocatalyst $\mathbf{5 c g}$ was obtained with a better yield when compared to the previously reported syntheses of the same compound (see Scheme 3 and Table 2, entry 18). ${ }^{10,11}$ In the previous procedures, the authors used an excess of amine $\mathbf{4 g}$ (1.5 equiv.), the most expensive part of this squaramide structure, in the second reaction step. However, we performed the reaction using equimolar amounts of each reagent in order to reduce the waste and costs involved in the process. Moreover, we stopped the reaction 3 hours after adding second amine $\mathbf{4 g}$, which is a notably shorter reaction time than those in previous procedures ( $24 \mathrm{~h}$, Scheme 3 ). As mentioned above, the yield of this process may be increased if the reaction is scaled up. 


\section{ARTICLE}

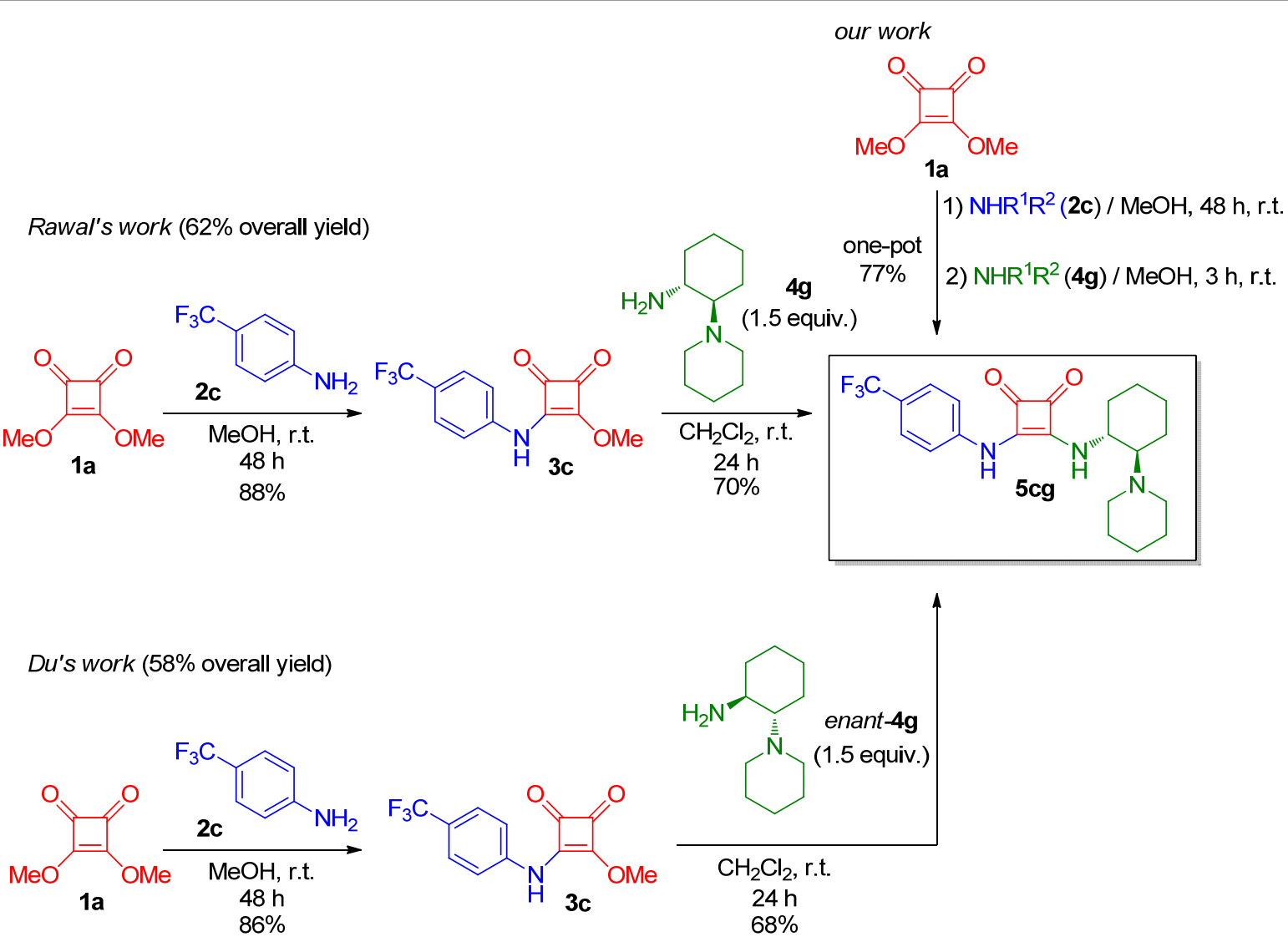

Scheme 3. Syntheses of commercially available squaramide $\mathbf{5 c g}$

After these promising results, we considered extending the applicability of our simple, cheap and straightforward methodology to the synthesis of biologically active compounds, in order to enlarge the scope of this method and to demonstrate the importance and applications of this pioneering one-pot procedure.

Recently, Moreno, Costa and co-workers have discovered an effective antiparasitic agent that acts as an anti-Chagasic drug (Scheme 4). Squaramide $\mathbf{1 0}$ has resulted to be a promising candidate in the preliminary in vivo studies on acute and chronic phases of Chagas disease and has shown low toxicity. ${ }^{16}$ This disease is a tropical parasitic infection that mainly affects to the poorest rural areas of Latin America, and although there are treatments for this illness, more efforts in research as well as more efficient and less expensive drugs are required to combat Chagas disease. ${ }^{17}$ In this context, squaramide 10, as a low-cost drug, could represent an interesting alternative to the medicines that are currently being used for this disease, the later having severe side effects and not being effective for chronic patients. 
Moreno and Costa's work (67.5\% overall yield, two final steps)<smiles>O=c1c(O)c(O)c1=O</smiles><smiles>[R17]Oc1c(OCC)c(=O)c1=O</smiles>

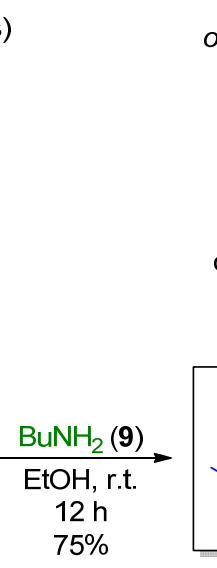

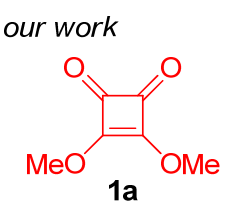

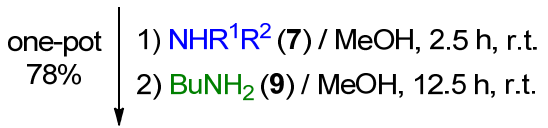

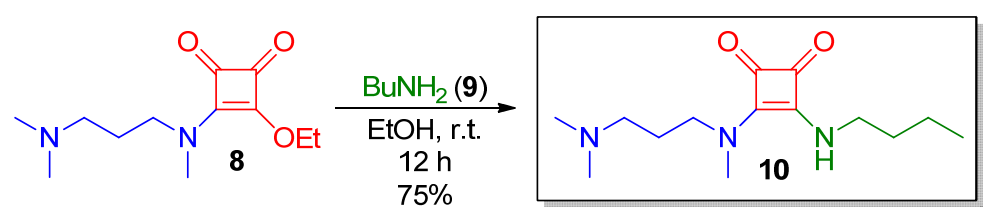

Scheme 4. Syntheses of anti-Chagasic squaramide 10

The results previously reported for the production of this interesting compound ${ }^{16}$ were improved when using our synthetic method. In the previous synthesis, the authors needed three sequential transformations with an overall yield for the last two steps of around $67.5 \%$. In contrast, we started our synthesis from squarate 1a dissolved in $\mathrm{MeOH}(0.25 \mathrm{~mL})$, and then added amine 7. In the same vessel, after $2.5 \mathrm{~h}$ we added $\mathrm{BuNH}_{2}$ (9) dissolved in $\mathrm{MeOH}(1.75 \mathrm{~mL})$. After $12.5 \mathrm{~h}$, the product was then purified by column chromatography, obtaining the final product $\mathbf{1 0}$ in a $78 \%$ yield. Therefore, the yield achieved using our one-pot procedure was higher than that of the previous three-step process.

This simple and inexpensive method might attract the interest of pharmaceutical companies for the production of this compound at a larger scale. This could help to overcome one of the drawbacks that this disease now presents: the high cost of the drugs used to fight it, which makes the treatment inaccessible for many people affected by this illness.
We also prepared two other active compounds, 14 and 18, as potent smooth muscle relaxants (Schemes 5 and 6). These two bladder-selective $\mathrm{K}_{\mathrm{ATP}}$-channel openers ${ }^{18}$ exhibit remarkable oral efficacy in a rat hypertrophied bladder model of urge urinary incontinency, ${ }^{19}$ a disease that affects between 10 to 20 percent of the worldwide population and causes enormous health care expenses. The therapeutic drugs that are currently being used to treat this disease, such as tolterodine, a muscarinic antagonist, present some drawbacks that limit their use and special care must be taken when supplying these drugs. These side effects have made it necessary to search for new candidates with different mechanisms of action that show enhanced efficacy and work in a wide range of patients. In this sense, WAY-133537 (14) and WAY-151616 (18) have been revealed as promising drug candidates since they show bladder selectivity without causing severe cardiovascular side effects.
Butera's work ( $17.7 \%$ overall yield)

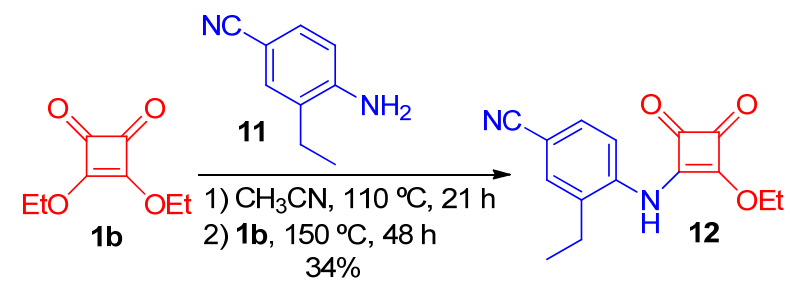

our work<smiles>COc1c(OC)c(=O)c1=O</smiles>

one-pot 1$) \mathrm{NHR}^{1} \mathrm{R}^{2}$ (11) / MeOH, 73 h, r.t.

$33 \%$ 2) $\mathrm{NHR}^{1} \mathrm{R}^{2}(13), 48$ h, r.t.

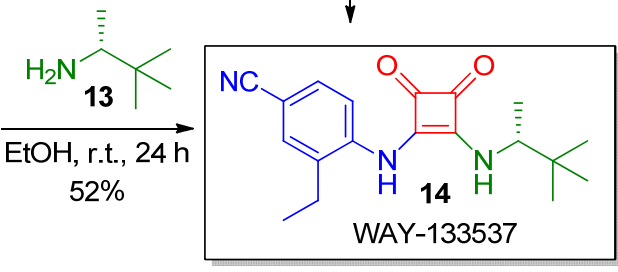




\section{ARTICLE}

The pioneering synthesis of compound $\mathbf{1 4}$ is described in Scheme 5 with an overall yield of $17.7 \%$ (scale of 5.88 mmol). ${ }^{20}$ Squaramide derivative $\mathbf{1 4}$ has been successfully tested in urinary incontinence disorder, but it is also efficient in the treatment of other diseases related to smooth muscle contraction such as hypertension, asthma, premature labor, irritable bowel syndrome, congestive heart failure, angina and cerebral vascular disease. ${ }^{21}$ The one-pot method that we have developed was also successfully employed in the synthesis of this appealing drug and it was possible to synthesise it in a $33 \%$ yield (at a scale of $0.2 \mathrm{mmol}$ ). In this case, the initial amount of solvent was slightly modified due to the high insolubility of intermediate 12, starting from squarate $\mathbf{1 a}$ and amine $\mathbf{1 1}$ dissolved in $1 \mathrm{~mL}$ of $\mathrm{MeOH}$. After $73 \mathrm{~h}$ of reaction, we added amine 13 as a liquid without $\mathrm{MeOH}$. Finally, after 2 days the precipitate was filtered under vacuum and the solid was washed with cold $\mathrm{MeOH}(1 \mathrm{~mL})$, obtaining the final product 14 in a $33 \%$ yield.

In addition, we also prepared WAY-151616 (18) using our new synthetic approach. Squaramide $\mathbf{1 8}$ is another potent potassium channel opener with specificity towards bladder tissue, which has also shown promising results as potential drug in the treatment of urge urinary incontinence and it is already being produced industrially (Scheme 6 ). ${ }^{21 \mathrm{~d}, 22}$

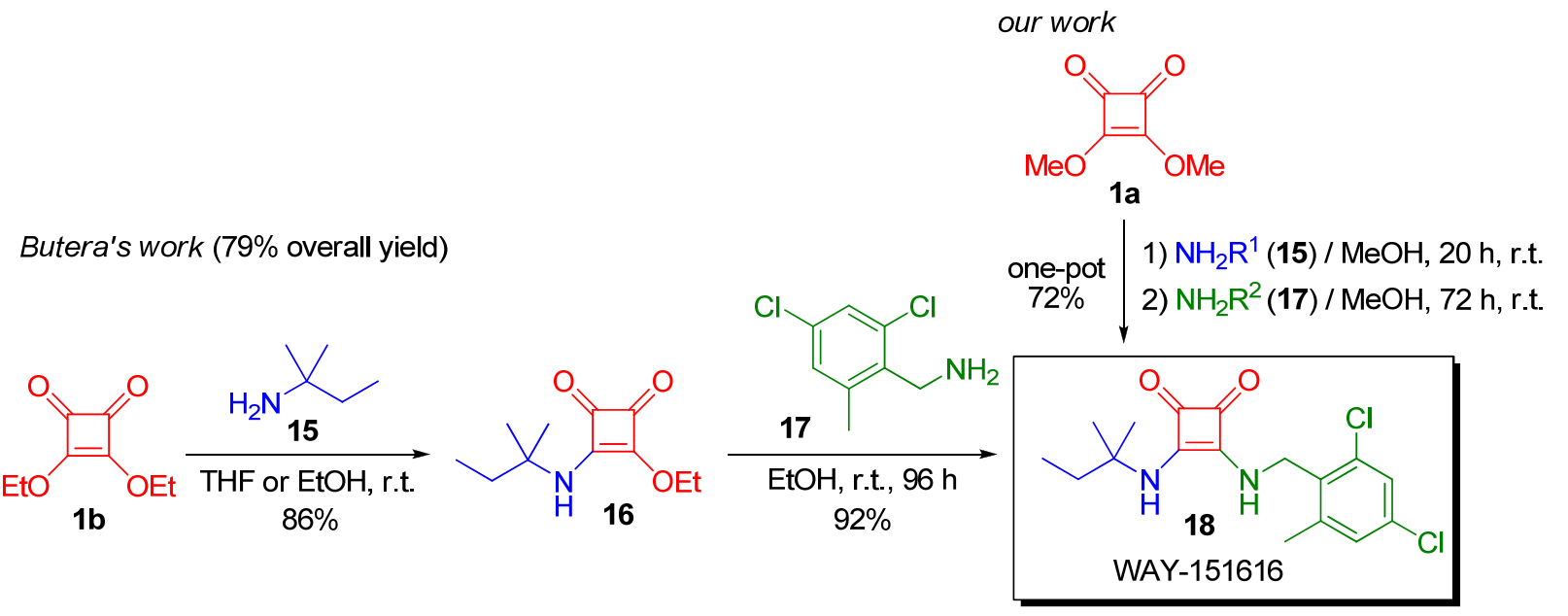

Scheme 6. Syntheses of biologically active WAY-151616 (18)

Biologically active squaramide $\mathbf{1 8}$ was prepared by Butera and co-workers following the procedure described in Scheme 6, with an overall yield of $79 \% .{ }^{23}$ Employing our one-pot method, we reached a $72 \%$ yield in one single step. It is noteworthy that the authors performed this synthesis to obtain around $28 \mathrm{~g}$ of compound 18 while we were operating on a very small scale $(0.4 \mathrm{mmol}$ of product, $136 \mathrm{mg})$. Therefore, a higher yield should be expected when employing our methodology on a larger scale. When we performed the reaction at a smaller scale $(0.2 \mathrm{mmol})$, the final product was rendered with a $62 \%$ yield, displaying the importance of scale and the possibility of improving our method by increasing the amount of product synthesised.

\section{Conclusions}

In summary, we have reported the first one-pot synthesis of squaramides with results from moderate to very good. This is a simpler procedure for obtaining appealing squaramide derivatives when compared to the previously developed "stopand-go" processes. This method is energy-saving, avoids time consuming purification steps and reduces costs, leading, in most cases, to better yields when compared to those obtained through the traditional sequential approach.

Furthermore, we have proved the utility of our process with the synthesis of three biologically active structures, improving upon the results of the previous stepwise syntheses. Moreover, we have been able to synthesise the commercially available squaramide $\mathbf{5 c g}$, which is being employed extensively as an organocatalyst, using this one-pot method and obtaining higher yields than those of previous works. This simple and inexpensive method could attract the interest of pharmaceutical and chemical companies aiming to produce these compounds at 
a large scale. We believe that our work could be a pivotal and crucial precedent in the field of squaramides due to the simplicity of the operational procedure reported here.

\section{Experimental}

\section{General Experimental Methods}

When need it, purification of reaction products was carried out by flash chromatography using silica-gel (0.063-0.200 mm). Analytical thin layer chromatography was performed on 0.25 $\mathrm{mm}$ silical gel $60-\mathrm{F}$ plates. ESI ionization method and mass analyzer type MicroTof-Q were used for the ESI measurements. ${ }^{1} \mathrm{H}$ NMR spectra were recorded at 400 and 300 $\mathrm{MHz} ;{ }^{13} \mathrm{C}$ APT-NMR spectra were recorded at 100 and 75 $\mathrm{MHz}$; DMSO- $d_{6}$ and $\mathrm{CDCl}_{3}$ as the solvents. Chemical shifts were reported in the $\delta$ scale relative to residual $\mathrm{CHCl}_{3}(7.26$ ppm) and DMSO (2.50 ppm) for ${ }^{1} \mathrm{H}$ NMR and to the central line of $\mathrm{CHCl}_{3}(77 \mathrm{ppm})$ and DMSO (39.43 ppm) for ${ }^{13} \mathrm{C}$ APTNMR.

All commercially available solvents and reagents were used as received. The ${ }^{1} \mathrm{H}$ and ${ }^{13} \mathrm{C}$ NMR spectra for compounds $5 \mathbf{a g}^{9}$

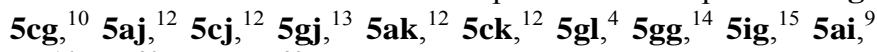
$\mathbf{1 0},{ }^{16} \mathbf{1 4},{ }^{20}$ and $\mathbf{1 8}^{23}$ are consistent with values previously reported in the literature.

\section{Representative procedure for the one-pot synthesis of} squaramides 5

To a mixture of 3,4-dimethoxy-3-cyclobutene-1,2-dione (1a) $(0.2 \mathrm{mmol})$ in $\mathrm{MeOH}(0.25-1 \mathrm{~mL})$, amine 2a-i was firstly added in one portion at room temperature. After the corresponding reaction time $\left(t_{1}\right)$ (see Table 1 ), amine 4a-l ( 1 equivalent) was then added dissolved in $\mathrm{MeOH}(1.75-1 \mathrm{~mL})$. After the corresponding reaction time $\left(\mathrm{t}_{2}\right)$ (see Table 1$)$, the product was purified by filtration or by column chromatography. Yields are reported in Table 1 and pure compounds were obtained as stable solids.

\section{One-pot synthesis of antiparasitic agent 10}

To a mixture of 3,4-dimethoxy-3-cyclobutene-1,2-dione (1a) $(0.2 \mathrm{mmol})$ in $\mathrm{MeOH}(0.25 \mathrm{~mL}), 0.2 \mathrm{mmol}$ of $N, N, N^{\prime}-$ trimethyl-1,3-propanediamine (7) was firstly added at room temperature in one portion. After $2.5 \mathrm{~h}, n$-butylamine (9) $(0.2$ mmol) was solved in $\mathrm{MeOH}(1.75 \mathrm{~mL})$ and added to the reaction mixture in one portion. After $12.5 \mathrm{~h}$, the solvent was evaporated in vacuum and the product was purified by column chromatography $\quad\left(\mathrm{SiO}_{2}, \quad\right.$ EtOAc:MeOH $1: 1$ to EtOAc:MeOH:Et ${ }_{3} \mathrm{~N}$ 5:5:0.1). Final anti-Chagasic drug 10 was obtained as a white solid in $78 \%$ yield.

\section{One-pot synthesis of WAY-133537 (14)}

To a mixture of 3,4-dimethoxy-3-cyclobutene-1,2-dione (1a) $(0.2$ $\mathrm{mmol})$ in $\mathrm{MeOH}(1 \mathrm{~mL}), 0.2 \mathrm{mmol}$ of 4-amino-3-ethylbenzonitrile (11) was firstly added at room temperature in one portion. After 73 h, $0.2 \mathrm{mmol}$ of $(R)$-3,3-dimethyl-2-butylamine (13) was added to the reaction mixture in one portion. After $48 \mathrm{~h}$, the test tube was placed in a freezer $\left(-22{ }^{\circ} \mathrm{C}\right)$ for 30 minutes to facilitate the overall precipitation of final drug 14. The product was filtered under vacuum and washed with cold $\mathrm{MeOH}(1 \mathrm{~mL})$. Final bladderselective agonist KATP channel $\mathbf{1 4}$ was obtained as a green solid in $33 \%$ yield.

\section{One-pot synthesis of WAY-151616 (18)}

To a mixture of 3,4-dimethoxy-3-cyclobutene-1,2-dione (1a) $(0.4 \mathrm{mmol})$ in $\mathrm{MeOH}(0.5 \mathrm{~mL}), 0.4 \mathrm{mmol}$ of $1,1-$ dimethylpropylamine (15) were firstly added at room temperature in one portion. After $20 \mathrm{~h}, 0.4 \mathrm{mmol}$ of 2,4dichloro-6-methylbenzylamine (17) were solved in $\mathrm{MeOH}$ (3.5 $\mathrm{mL}$ ) and added to the reaction mixture in one portion. After 72 $\mathrm{h}$, the solvent was evaporated under vacuum and the product was purified by column chromatography $\left(\mathrm{SiO}_{2}\right.$, hexane/EtOAc 6:4 to $0: 1$ and EtOAc/MeOH 9:1. Final bladder-selective agonist KATP channel 18 was obtained as a white solid in $72 \%$ yield.

\section{$N$-((1R,2R)-2-(2-(3,5-Bis(trifluoromethyl)phenylamino)-3,4- dioxocyclobut-1-enylamino)cyclohexyl)-4- methylbenzenesulfonamide (5aa)}

Following the general procedure, compound 5aa was obtained after $100 \mathrm{~h}$ of reaction at room temperature as a white solid in $75 \%$ yield. $[\alpha]_{\mathrm{D}}{ }^{25}=+34(c 0.55, \mathrm{DMSO}) .{ }^{1} \mathrm{H}$ NMR $\left(400 \mathrm{MHz}, \mathrm{DMSO}-d_{6}\right) \delta$ 10.02 (br s, 1H), 8.06 (s, 2H), 7.74 (br d, $J=8.5 \mathrm{~Hz}, 1 \mathrm{H}), 7.69$ (s, 1H), 7.63 (br d, $J=8.9 \mathrm{~Hz}, 1 \mathrm{H}), 7.59$ (d, $J=8.2 \mathrm{~Hz}, 2 \mathrm{H}), 7.21$ (d, $J$ $=8.0 \mathrm{~Hz}, 2 \mathrm{H}), 3.62-3.52(\mathrm{~m}, 1 \mathrm{H}), 3.18-3.05(\mathrm{~m}, 1 \mathrm{H}), 2.13(\mathrm{~s}, 3 \mathrm{H})$, 1.92-1.89 (m, 1H), 1.72-1.37 (m, 4H), 1.35-1.10 (m, 3H). ${ }^{13} \mathrm{C}$ APTNMR $\left(100 \mathrm{MHz}, \mathrm{DMSO}_{6}\right) \delta 183.8(1 \mathrm{C}), 179.8(1 \mathrm{C}), 169.5$ (1C), 162.0 (1C), 141.7 (1C), 141.1 (1C), 139.3 (1C), 131.4 (q, $J=34.2$ $\mathrm{Hz}, 2 \mathrm{C}), 130.9$ (2C), 125.9 (2C), 123.1 (q, $J=271.7 \mathrm{~Hz}, 2 \mathrm{C}), 117.6$ (2C), 114 (1C), 57.3 (1C), 56.8 (1C), 32.7 (1C), 32.6 (1C), 24.0 (1C), 24.0 (1C), 20.5 (1C). IR (KBr film) $\left(\mathrm{cm}^{-1}\right)$ v 3284, 3177, 2924, 2854, 1793, 1659, 1582, 1559, 1457, 1379, 1277, 1191, 1163, 1151, 1129, 1093, 880, 754, 666. HRMS (ESI+) calcd $\mathrm{C}_{25} \mathrm{H}_{24} \mathrm{~F}_{6} \mathrm{~N}_{3} \mathrm{O}_{4} \mathrm{~S}$ 576.1392; found $576.1360[\mathrm{M}+\mathrm{H}]$.

\section{$N$-((1R,2R)-2-(2-(3,5-Difluorophenylamino)-3,4- dioxocyclobut-1-enylamino)cyclohexyl)-4- methylbenzenesulfonamide (5ba)}

Following the general procedure, compound 5ba was obtained after $51 \mathrm{~h}$ of reaction at room temperature as a white solid in $82 \%$ yield. $[\alpha]_{\mathrm{D}}{ }^{25}=+42\left(c 0.49\right.$, DMSO). ${ }^{1} \mathrm{H}$ NMR $(400 \mathrm{MHz}$, DMSO- $\left.d_{6}\right) \delta 9.69$ (br s, $\left.1 \mathrm{H}\right), 7.70(\mathrm{~d}, J=8.5 \mathrm{~Hz}, 1 \mathrm{H}), 7.67$ (d, $J$ $=8.8 \mathrm{~Hz}, 1 \mathrm{H}), 7.59(\mathrm{~d}, J=7.9 \mathrm{~Hz}, 2 \mathrm{H}), 7.23-7.18(\mathrm{~m}, 4 \mathrm{H}), 6.86$ $(\mathrm{t}, J=9.2 \mathrm{~Hz}, 1 \mathrm{H}), 3.60-3.53(\mathrm{~m}, 1 \mathrm{H}), 3.16-3.09(\mathrm{~m}, 1 \mathrm{H}), 2.17$ (s, 3H), 1.92-1.89 (m, 1H), 1.64-1.11 (m, 7H). ${ }^{13} \mathrm{C}$ APT-NMR (100 MHz, DMSO-d $d_{6} \delta 183.6$ (1C), 179.6 (1C), 169.2 (1C), $163.0(\mathrm{~d}, J=242.7 \mathrm{~Hz}, 1 \mathrm{C}), 162.9$ (d, $J=243.9 \mathrm{~Hz}, 1 \mathrm{C}), 162.4$ (1C), 141.9 (1C), 141.8 (t, $J=13.8 \mathrm{~Hz}, 1 \mathrm{C}), 139.3$ (1C), 129.2 (2C), 125.9 (2C), 100.9 (d, $J=29.6 \mathrm{~Hz}, 2 \mathrm{C}), 97.1(\mathrm{t}, J=26.6$ $\mathrm{Hz}, 1 \mathrm{C}), 57.2$ (1C), 56.9 (1C), 32.8 (1C), 32.6 (1C), 24.0 (1C), 24.0 (1C), 20.6 (1C). IR ( $\mathrm{KBr}$ film) $\left(\mathrm{cm}^{-1}\right)$ v 3369, 3289, 3189, 
3044, 2924, 2854, 1797, 1664, 1616, 1575, 1536, 1461, 1377, 1319, 1205, 1158, 1118, 1089, 994, 854, 749, 670, 571. MS (ESI+) $476.2[\mathrm{M}+\mathrm{H}]$.

$N$-((1R,2R)-2-(2-(4-tert-Butylphenylamino)-3,4-dioxocyclobut-1enylamino)cyclohexyl)-4-methylbenzenesulfonamide (5da)

Following the general procedure, compound 5da was obtained after $6.5 \mathrm{~h}$ of reaction at room temperature as a white solid in $80 \%$ yield. $[\alpha]_{\mathrm{D}}{ }^{24}=+48(c 0.52, \mathrm{DMSO}) .{ }^{1} \mathrm{H}$ NMR $(400 \mathrm{MHz}$, DMSO- $\left.d_{6}\right) \delta 9.40$ (br s, $\left.1 \mathrm{H}\right), 7.65$ (br d, $\left.J=8.1 \mathrm{~Hz}, 1 \mathrm{H}\right), 7.59$ $(\mathrm{d}, J=8.2 \mathrm{~Hz}, 2 \mathrm{H}), 7.51(\mathrm{br} \mathrm{d}, J=7.1 \mathrm{~Hz}, 1 \mathrm{H}), 7.43-7.35(\mathrm{~m}$, $4 \mathrm{H}), 7.21(\mathrm{~d}, J=8.1 \mathrm{~Hz}, 2 \mathrm{H}), 3.60-3.43(\mathrm{~m}, 1 \mathrm{H}), 3.12-3.07(\mathrm{~m}$, $1 \mathrm{H}), 2.13(\mathrm{~s}, 3 \mathrm{H}), 1.94-1.87(\mathrm{~m}, 1 \mathrm{H}), 1.69-1.11(\mathrm{~m}, 7 \mathrm{H}), 1.28$ $(\mathrm{s}, 9 \mathrm{H}) .{ }^{13} \mathrm{C}$ APT-NMR (100 MHz, DMSO-d $d_{6} \delta 183.0$ (1C), 179.8 (1C), 168.6 (1C), 163.5 (1C), 144.9 (1C), 142.0 (1C), 139.2 (1C), 136.5 (1C), 129.2 (2C), 125.9 (4C), 117.5 (2C), 57.0 (1C), 56.9 (1C), 33.9 (1C), 32.9 (1C), 32.7 (1C), 31.1 (3C), 24.1 (1C), 24.0 (1C), 20.6 (1C). IR ( $\mathrm{KBr}$ film) $\left(\mathrm{cm}^{-1}\right) v$ 3343, 3195, 2924, 2854, 1795, 1660, 1604, 1568, 1535, 1460, $1375,1322,1268,1162,1143,1094,829,723,667$. HRMS (ESI+) calcd $\mathrm{C}_{27} \mathrm{H}_{34} \mathrm{~N}_{3} \mathrm{O}_{4} \mathrm{~S} 469.2270$; found $469.2233[\mathrm{M}+\mathrm{H}]$.

$N$-((1R,2R)-2-(2-(4-Methoxyphenylamino)-3,4-

dioxocyclobut-1-enylamino)cyclohexyl)-4-

methylbenzenesulfonamide (5ea)

Following the general procedure, compound 5ea was obtained after $10 \mathrm{~h}$ of reaction at room temperature as a white solid in $85 \%$ yield. $[\alpha]_{\mathrm{D}}{ }^{24}=+40(c 0.58, \mathrm{DMSO}) .{ }^{1} \mathrm{H}$ NMR $(400 \mathrm{MHz}$, DMSO-d $\left.d_{6}\right) \delta 9.35$ (br s, $1 \mathrm{H}$ ), 7.64 (br d, $\left.J=8.4 \mathrm{~Hz}, 1 \mathrm{H}\right), 7.59$ (d, $J=8.2 \mathrm{~Hz}, 2 \mathrm{H}), 7.42$ (br d, $J=7.1 \mathrm{~Hz}, 1 \mathrm{H}), 7.37$ (d, $J=8.7$ $\mathrm{Hz}, 2 \mathrm{H}), 7.22$ (d, $J=8.0 \mathrm{~Hz}, 2 \mathrm{H}), 6.95(\mathrm{~d}, J=9.0 \mathrm{~Hz}, 2 \mathrm{H}), 3.74$ $(\mathrm{s}, 3 \mathrm{H}), 3.59-3.50(\mathrm{~m}, 1 \mathrm{H}), 3.16-3.06(\mathrm{~m}, 1 \mathrm{H}), 2.16(\mathrm{~s}, 3 \mathrm{H})$, 1.91-1.88 (m, 1H), 1.67-1.17 (m, 7H). ${ }^{13} \mathrm{C}$ APT-NMR $(100$ $\left.\mathrm{MHz}, \mathrm{DMSO}-d_{6}\right) \delta 182.6(1 \mathrm{C}), 179.9$ (1C), 168.3 (1C), 163.4 (1C), 155.0 (1C), 142.0 (1C), 139.2 (1C), 132.2 (1C), 129.2 (2C), 125.9 (2C), 119.2 (2C), 114.5 (2C), 56.9 (1C), 56.9 (1C), 55.2 (1C), 32.9 (1C), 32.8 (1C), 24.1 (1C), 24.0 (1C), 20.7 (1C). IR (KBr film) $\left(\mathrm{cm}^{-1}\right) \vee 3348,3266,2922,2853,1790$, 1646, 1613, 1564, 1538, 1515, 1477, 1368, 1323, 1251, 1160, 1094, 1077, 829, 810, 665. HRMS (ESI+) calcd $\mathrm{C}_{24} \mathrm{H}_{28} \mathrm{~N}_{3} \mathrm{O}_{5} \mathrm{~S}$ 470.1750; found $470.1729[\mathrm{M}+\mathrm{H}]$.

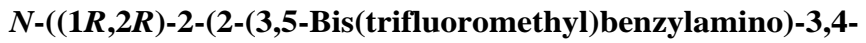
dioxocyclobut-1-enylamino)cyclohexyl)-4methylbenzenesulfonamide (5ga)

Following the general procedure, compound 5ga was obtained after $23 \mathrm{~h}$ of reaction at room temperature as a white solid in $72 \%$ yield $(85 \mathrm{mg}) .[\alpha]_{\mathrm{D}}{ }^{24}=+33\left(c 0.49\right.$, DMSO). ${ }^{1} \mathrm{H}$ NMR $\left(400 \mathrm{MHz}, \mathrm{DMSO}-d_{6}\right) \delta 8.09(\mathrm{~s}, 2 \mathrm{H}), 8.05(\mathrm{~s}, 1 \mathrm{H}), 7.80(\mathrm{br} \mathrm{s}$, $1 \mathrm{H}), 7.61(\mathrm{~d}, J=8.2 \mathrm{~Hz}, 2 \mathrm{H}), 7.57$ (br s, $1 \mathrm{H}), 7.38$ (br s, $1 \mathrm{H})$, 7.27 (d, $J=8.1 \mathrm{~Hz}, 2 \mathrm{H}), 4.90$ (br s, $2 \mathrm{H}), 3.60-3.45(\mathrm{~m}, 1 \mathrm{H})$, 3.04-2.94 (m, 1H), $2.33(\mathrm{~s}, 3 \mathrm{H}), 1.86-1.80(\mathrm{~m}, 1 \mathrm{H}), 1.60-1.01$ $(\mathrm{m}, 7 \mathrm{H}) .{ }^{13} \mathrm{C}$ APT-NMR (100 MHz, DMSO- $\left.d_{6}\right) \delta 182.1$ (1C), 168.0 (1C), 142.5 (1C), 141.1 (2C), 139.3 (2C), 130.4 (q, $J=$ $32.5 \mathrm{~Hz}, 2 \mathrm{C}), 129.3(2 \mathrm{C}), 128.4$ (2C), 126.0 (2C), 123.2 (q, $J=$ $271.2 \mathrm{~Hz}, 2 \mathrm{C}), 121.1$ (1C), 56.9 (1C), 56.7 (1C), 45.6 (1C),
32.8 (1C), 32.1 (1C), 24.0 (2C), 20.8 (1C). IR (KBr film) (cm 1) v 3373, 3166, 2924, 2854, 1798, 1650,1569, 1496, 1456, $1377,1321,1268,1237,1203,1186,1171,1095,894,729$, 706, 682, 568. MS (ESI+) $590.2[\mathrm{M}+\mathrm{H}]$.

(S)-3-(3,5-bis(Trifluoromethyl)phenylamino)-4-(2-hydroxy1,2,2-triphenylethylamino)cyclobut-3-ene-1,2-dione (5ab)

Following the general procedure, compound $\mathbf{5 a b}$ was obtained after $92 \mathrm{~h}$ of reaction at room temperature as a white solid in $77 \%$ yield. $[\alpha]_{\mathrm{D}}{ }^{25}=-97\left(c 0.40\right.$, DMSO). ${ }^{1} \mathrm{H}$ NMR (400 MHz, DMSO- $\left.d_{6}\right) \delta 10.40$ (br s, $\left.1 \mathrm{H}\right), 8.74$ (br d, $\left.J=9.6 \mathrm{~Hz}, 1 \mathrm{H}\right), 8.00$ (s, 2H), $7.67(\mathrm{~d}, J=7.5 \mathrm{~Hz}, 2 \mathrm{H}), 7.63(\mathrm{~s}, 1 \mathrm{H}), 7.41-7.05(\mathrm{~m}$, 13H), 6.71 (br s, 1H), 6.22 (br d, $J=9.7 \mathrm{~Hz}, 1 \mathrm{H}) .{ }^{13} \mathrm{C} \mathrm{APT}-$ NMR (100 MHz, DMSO-d $d_{6} \delta 184.6$ (1C), 179.9 (1C), 168.3 (1C), 162.5 (1C), 145.5 (1C), 144.1 (1C), 140.8 (1C), 138.9 (1C), 131.2 (q, $J=31.6 \mathrm{~Hz}, 2 \mathrm{C}), 128.8$ (2C), 128.0 (2C), 127.5 (1C) $127.4(2 \mathrm{C}), 127.0(1 \mathrm{C}), 126.7$ (1C), 126.5 (1C), 126.3 (1C), 126.1 (2C), 126.0 (2C), 123.0 (q, $J=271.0 \mathrm{~Hz}, 2 \mathrm{C})$, 118.0 (2C), 114.6 (1C), 80.4 (1C), 63.3 (1C). IR (KBr film) $\left(\mathrm{cm}^{-1}\right) \vee 3506,3220,3135,2923,2854,1804,1660,1604$, $1575,1546,1506,1469,1380,1280,1184,1128,1062,889$, 752, 699. HRMS (ESI+) calcd $\mathrm{C}_{32} \mathrm{H}_{23} \mathrm{~F}_{6} \mathrm{~N}_{2} \mathrm{O}_{3}$ 597.1613; found $597.1599[\mathrm{M}+\mathrm{H}]$.

(S)-3-(3,5-Difluorophenylamino)-4-(2-hydroxy-1,2,2triphenylethylamino)cyclobut-3-ene-1,2-dione (5bb)

Following the general procedure, compound $\mathbf{5 b b}$ was obtained after $62 \mathrm{~h}$ of reaction at room temperature as a white solid in $>95 \%$ yield. $[\alpha]_{\mathrm{D}}{ }^{27}=-197$ (c 0.65, DMSO). ${ }^{1} \mathrm{H}$ NMR (400 MHz, DMSO- $\left.d_{6}\right) \delta 10.12$ (br s, $\left.1 \mathrm{H}\right), 8.73($ br d, $J=9.7 \mathrm{~Hz}, 1 \mathrm{H})$, $7.6(\mathrm{~d}, J=7.5 \mathrm{~Hz}, 2 \mathrm{H}), 7.35(\mathrm{t}, J=7.6 \mathrm{~Hz}, 2 \mathrm{H}), 7.25-7.05(\mathrm{~m}$, $13 \mathrm{H}), 6.85-6.79(\mathrm{~m}, 1 \mathrm{H}), 6.69$ (br s, $1 \mathrm{H}), 6.23$ (br d, $J=9.8 \mathrm{~Hz}$, 1H). ${ }^{13} \mathrm{C}$ APT-NMR (100 MHz, DMSO- $\left.d_{6}\right) \delta 184.5$ (1C), 179.7 (1C), 168.1 (1C), 162.9 (d, $J=242.5 \mathrm{~Hz}, 1 \mathrm{C}), 162.8$ (1C), 162.7 (d, $J=232.5 \mathrm{~Hz}, 1 \mathrm{C}), 145.6$ (1C), 144.1 (1C), 141.5 (t, $J$ $=13.7 \mathrm{~Hz}, 1 \mathrm{C}), 139.0(1 \mathrm{C}), 128.9(2 \mathrm{C}), 128.0$ (2C), $127.4(4 \mathrm{C})$ 127.0 (1C), 126.7 (1C), 126.5 (1C), 126.2 (2C), 126.1 (2C), 101.2 (d, $J=29.5 \mathrm{~Hz}, 2 \mathrm{C}), 97.4$ (t, $J=26.5 \mathrm{~Hz}, 1 \mathrm{C}) 80.4$ (1C), 63.3 (1C). IR (KBr film) $\left(\mathrm{cm}^{-1}\right) \vee 3483,3446,3227,3122$, 2924, 2853, 1800, 1656, 1608, 1565, 1493, 1465, 1377, 1188, $1166,1119,1065,1004,891,761,750,728,697$. MS (ESI) $497.2[\mathrm{M}+\mathrm{H}]$.

(R)-3-(3,5-Bis(trifluoromethyl)phenylamino)-4-(1phenylethylamino)cyclobut-3-ene-1,2-dione (5ac)

Following the general procedure, compound 5ac was obtained after $85 \mathrm{~h}$ of reaction at room temperature as a white solid in $84 \%$ yield. $[\alpha]_{\mathrm{D}}{ }^{27}=-6(\mathrm{c} 0.87, \mathrm{DMSO}) .{ }^{1} \mathrm{H}$ NMR (400 MHz, DMSO- $\left.d_{6}\right) \delta 10.06$ (br s, $\left.1 \mathrm{H}\right), 8.15($ br s, $1 \mathrm{H}), 8.01(\mathrm{~s}, 2 \mathrm{H}), 7.67$ $(\mathrm{s}, 1 \mathrm{H}), 7.44-7.30(\mathrm{~m}, 5 \mathrm{H}), 5.36-5.27(\mathrm{~m}, 1 \mathrm{H}), 1.61(\mathrm{~d}, J=6.9$ $\mathrm{Hz}, 3 \mathrm{H}) .{ }^{13} \mathrm{C}$ APT-NMR (100 MHz, DMSO- $\left.d_{6}\right) \delta 184.3$ (1C), 180.5 (1C), 168.8 (1C), 162.5 (1C), 142.7 (1C), 140.9 (1C), $131.2(\mathrm{q}, J=34.0 \mathrm{~Hz}, 2 \mathrm{C}), 128.6$ (2C), 127.5 (1C), 126.0 (2C), 123.0 (q, $J=271.2 \mathrm{~Hz}, 2 \mathrm{C}), 118.0$ (2C), 114.7 (1C), 53.3 (1C), 22.7 (1C). IR (KBr film) $\left(\mathrm{cm}^{-1}\right) \vee 3135,2924,1797,1661$, 
1570, 1559, 1491, 1456, 1377, 1275, 1188, 1170, 1129, 944, 883, 750, 697, 683, 667. MS (ESI+) 429.1 [M+H].

(R)-3-(3,5-Bis(trifluoromethyl)phenylamino)-4-(1-hydroxy3-phenylpropan-2-ylamino)cyclobut-3-ene-1,2-dione (5ad) Following the general procedure, compound 5ad was obtained after $96 \mathrm{~h}$ of reaction at room temperature as a white solid in $60 \%$ yield. $[\alpha]_{\mathrm{D}}{ }^{24}=+125(c 0.54, \mathrm{DMSO}) .{ }^{1} \mathrm{H}$ NMR $(400 \mathrm{MHz}$, DMSO- $\left.d_{6}\right) \delta 9.78$ (br s, 1H), 7.59 (s, 2H), 7.47 (br d, $J=9.0$ $\mathrm{Hz}, 1 \mathrm{H}), 7.19$ (s, 1H), 6.85-6.73 (m, 5H), 4.78 (br s, 1H), 3.90$3.80(\mathrm{~m}, 1 \mathrm{H}), 3.15-3.06(\mathrm{~m}, 2 \mathrm{H}), 2.51(\mathrm{dd}, J=6.6,13.6 \mathrm{~Hz}$, $1 \mathrm{H}), 2.38(\mathrm{dd}, J=7.9,13.4 \mathrm{~Hz}, 1 \mathrm{H}) .{ }^{13} \mathrm{C}$ APT-NMR $(100 \mathrm{MHz}$, DMSO- $\left.d_{6}\right) \delta 184.2$ (1C), 180.1 (1C), 169.5 (1C), 162.0 (1C), 141.1 (1C), 137.8 (1C), 131.3 (q, $J=33.6 \mathrm{~Hz}, 2 \mathrm{C}$ ), 129.2 (2C), 128.2 (2C), 126.2 (1C), 123.1 (q, $J=270.9 \mathrm{~Hz}, 2 \mathrm{C}), 117.7$ (2C), 114.5 (1C), 62.2 (1C), 57.4 (1C), 38.0 (1C). IR ( $\mathrm{KBr}$ film) $\left(\mathrm{cm}^{-1}\right) \vee 3280,3044,2923,2853,1790,1690,1605,1576$, 1553, 1499, 1477, 1455, 1388, 1280, 1181, 1171, 1131, 1030, 899, 882, 701. HRMS (ESI+) calcd $\mathrm{C}_{21} \mathrm{H}_{17} \mathrm{~F}_{6} \mathrm{~N}_{2} \mathrm{O}_{3}$ 459.1144; found $459.1130[\mathrm{M}+\mathrm{H}]$.

\section{3-(3,5-Bis(trifluoromethyl)phenylamino)-4-((1S,2R)-2-} hydroxy-2,3-dihydro-1H-inden-1-ylamino)cyclobut-3-ene1,2-dione (5ae)

Following the general procedure, compound 5ae was obtained after $52 \mathrm{~h}$ of reaction at room temperature as a white solid in $61 \%$ yield. $[\alpha]_{\mathrm{D}}{ }^{27}=+81(c 0.48, \mathrm{DMSO}) .{ }^{1} \mathrm{H}$ NMR $(400 \mathrm{MHz}$, DMSO- $\left.d_{6}\right) \delta 10.46$ (br s, $\left.1 \mathrm{H}\right), 8.16$ (br d, $\left.J=9.0 \mathrm{~Hz}, 1 \mathrm{H}\right), 8.10$ (s, 2H), $7.65(\mathrm{~s}, 1 \mathrm{H}), 7.32-7.22(\mathrm{~m}, 4 \mathrm{H}), 5.62$ (br s, 1H), 5.53 $(\mathrm{dd}, J=5.0,8.7 \mathrm{~Hz}, 1 \mathrm{H}), 4.65-4.55(\mathrm{~m}, 1 \mathrm{H}), 3.16(\mathrm{dd}, J=4.8$, $16.4 \mathrm{~Hz}, 1 \mathrm{H}), 2.89(\mathrm{~d}, J=16.2 \mathrm{~Hz}, 1 \mathrm{H}) .{ }^{13} \mathrm{C}$ APT-NMR $(100$ $\left.\mathrm{MHz}, \mathrm{DMSO}-d_{6}\right) \delta 184.6(1 \mathrm{C}), 180.4(1 \mathrm{C}), 169.5$ (1C), 162.6 (1C), 141.2 (1C), 141.2 (1C), 140.5 (1C), 131.3 (q, $J=32.7 \mathrm{~Hz}$, 2C), 128.0 (2C), 126.6 (1C), 125.1 (1C), 124.2 (1C), 123.1 (q, $J$ $=271.1 \mathrm{~Hz}, 2 \mathrm{C}), 117.8(2 \mathrm{C}), 114.5$ (1C), 72.2 (1C), 62.2 (1C). IR $(\mathrm{KBr}$ film $)\left(\mathrm{cm}^{-1}\right) \vee 3278,2958,2927,2854,1792,1691$, $1597,1552,1482,1465,1442,1383,1334,1300,1190,1128$, 1043, 933, 897, 742, 685. MS (ESI+) 457.1 [M+H].

3-(3,5-Difluorophenylamino)-4-((1S,2R)-2-hydroxy-2,3dihydro-1H-inden-1-ylamino)cyclobut-3-ene-1,2-dione (5be) Following the general procedure, compound 5 be was obtained after $40 \mathrm{~h}$ of reaction at room temperature as a white solid in $88 \%$ yield. $[\alpha]_{\mathrm{D}}{ }^{27}=+48(c 0.47, \mathrm{DMSO}) .{ }^{1} \mathrm{H}$ NMR $(400 \mathrm{MHz}$, DMSO- $d_{6}$ ) $\delta 10.16$ (br s, $\left.1 \mathrm{H}\right), 8.17$ (br d, $\left.J=9.4 \mathrm{~Hz}, 1 \mathrm{H}\right), 7.32$ $7.23(\mathrm{~m}, 6 \mathrm{H}), 6.85(\mathrm{t}, J=9.5 \mathrm{~Hz}, 1 \mathrm{H}), 5.58(\mathrm{br} \mathrm{s}, 1 \mathrm{H}), 5.52(\mathrm{dd}$, $J=5.0,9.0 \mathrm{~Hz}, 1 \mathrm{H}), 4.60-4.56(\mathrm{~m}, 1 \mathrm{H}), 3.14(\mathrm{dd}, J=4.0,15.7$ $\mathrm{Hz}, 1 \mathrm{H}), 2.87(\mathrm{~d}, J=16.3 \mathrm{~Hz}, 1 \mathrm{H}) .{ }^{13} \mathrm{C}$ APT-NMR $(100 \mathrm{MHz}$, DMSO- $\left.d_{6}\right) \delta 184.4(1 \mathrm{C}), 180.2(1 \mathrm{C}), 169.3(1 \mathrm{C}), 163.0$ (d, $J=$ $238.2 \mathrm{~Hz}, 1 \mathrm{C}), 162.8$ (1C), 162.9 (d, $J=242.5 \mathrm{~Hz}, 1 \mathrm{C}), 141.9$ (t, $J=13.7 \mathrm{~Hz}, 1 \mathrm{C}), 141.1$ (1C), 140.5 (1C), 128.0 (1C), 126.6 (1C), 125.1 (1C), 124.2 (1C), $101.0(\mathrm{~d}, J=29.4 \mathrm{~Hz}, 2 \mathrm{C}), 97.2$ (d, $J=26.1 \mathrm{~Hz}, 1 \mathrm{C}), 72.3$ (1C), 61.2 (1C), 39.4 (1C). IR ( $\mathrm{KBr}$ film) $\left(\mathrm{cm}^{-1}\right) \vee 3460,3261,2922,2852,1794,1662,1613,1576$, $1559,1541,1446,1416,1377,1208,1149,1119,1090,1022$, 995, 977, 854, 752, 727, 686, 646. MS (ESI+) $357.1[\mathrm{M}+\mathrm{H}]$.
(S)-3-(3,5-Difluorophenylamino)-4-(1-(naphthalen-1yl)ethylamino)cyclobut-3-ene-1,2-dione (5bf)

Following the general procedure, compound $\mathbf{5 b f}$ was obtained after $33 \mathrm{~h}$ of reaction at room temperature as a white solid in $82 \%$ yield. $[\alpha]_{\mathrm{D}}{ }^{27}=+184(c 0.44, \mathrm{DMSO}) .{ }^{1} \mathrm{H} \mathrm{NMR}(400 \mathrm{MHz}$, DMSO- $d_{6}$ ) $\delta 9.80$ (br s, $\left.1 \mathrm{H}\right), 8.28$ (br d, $\left.J=6.9 \mathrm{~Hz}, 1 \mathrm{H}\right), 8.14$ $(\mathrm{d}, J=8.4 \mathrm{~Hz}, 1 \mathrm{H}), 7.99$ (d, $J=7.8 \mathrm{~Hz}, 1 \mathrm{H}), 7.93(\mathrm{~d}, J=8.0$ $\mathrm{Hz}, 1 \mathrm{H}), 7.67-7.55(\mathrm{~m}, 4 \mathrm{H}), 7.16(\mathrm{br} \mathrm{d}, J=7.6 \mathrm{~Hz}, 2 \mathrm{H}), 6.84(\mathrm{t}$, $J=9.3 \mathrm{~Hz}, 1 \mathrm{H}), 6.17-6.08(\mathrm{~m}, 1 \mathrm{H}), 1.75(\mathrm{~d}, J=6.7 \mathrm{~Hz}, 3 \mathrm{H})$. ${ }^{13} \mathrm{C}$ APT-NMR (100 MHz, DMSO-d $\left.d_{6}\right) \delta 184.1$ (1C), 180.1 (1C), 168.4 (1C), 162.9 (d, $J=242.5 \mathrm{~Hz}, 1 \mathrm{C}), 162.8$ (1C), $162.8(\mathrm{~d}, J=242.5 \mathrm{~Hz}, 1 \mathrm{C}), 141.6(\mathrm{t}, J=13.7 \mathrm{~Hz}, 1 \mathrm{C}), 138.1$ (1C), 133.4 (1C), 129.9 (1C), 128.7 (1C), 128.2 (1C), 126.7 (1C), 125.9 (1C), 125.4 (1C), 122.7 (1C), 122.6 (1C), 101.1 (d, $J=29.4 \mathrm{~Hz}, 2 \mathrm{C}), 97.4(\mathrm{t}, J=26.2 \mathrm{~Hz}, 1 \mathrm{C}), 49.4$ (1C), 22.7 (1C). IR (KBr film) $\left(\mathrm{cm}^{-1}\right) \vee 3165,3080,3017,2924,2854$, 1793, 1664, 1631, 1609, 1460, 1375, 1307, 1153, 1116, 993, 854, 835, 804, 782, 754. MS (ESI+) $379.2[\mathrm{M}+\mathrm{H}]$.

3-((1R,2R)-2-(Piperidin-1-yl)cyclohexylamino)-4-(3,4,5trifluorophenylamino)cyclobut-3-ene-1,2-dione (5fg) Following the general procedure, compound $\mathbf{5 f g}$ was obtained after $69 \mathrm{~h}$ of reaction at room temperature as a white solid in $82 \%$ yield. $[\alpha]_{\mathrm{D}}{ }^{25}=-54(c 0.40, \mathrm{DMSO}) .{ }^{1} \mathrm{H}$ NMR $(400 \mathrm{MHz}$, DMSO- $\left.d_{6}\right) \delta 9.92$ (br s, $\left.1 \mathrm{H}\right), 7.52$ (br s, $\left.1 \mathrm{H}\right), 7.33$ (d, $J=9.7$ $\mathrm{Hz}, 1 \mathrm{H}), 7.31(\mathrm{~d}, J=9.5 \mathrm{~Hz}, 1 \mathrm{H}), 4.02-3.85(\mathrm{~m}, 1 \mathrm{H}), 2.76-2.56$ $(\mathrm{m}, 2 \mathrm{H}), 2.39-2.17(\mathrm{~m}, 3 \mathrm{H}), 2.10-1.97(\mathrm{~m}, 1 \mathrm{H}), 1.91-1.80(\mathrm{~m}$, $1 \mathrm{H}), 1.79-1.60(\mathrm{~m}, 2 \mathrm{H}), 1.51-1.00(\mathrm{~m}, 10 \mathrm{H}) .{ }^{13} \mathrm{C}$ APT-NMR $\left(100 \mathrm{MHz}, \mathrm{DMSO}-d_{6}\right) \delta 184.5$ (1C), 180.1 (1C), 169.6 (1C), 161.7 (2C), 150.6 (dd, $J=10.0,245.8 \mathrm{~Hz}, 1 \mathrm{C}), 150.5$ (dd, $J=$ 10.0, 244.7 Hz, 1C), 134.3 (dt, $J=15.6,243.0 \mathrm{~Hz}, 1 \mathrm{C}), 102.5$ (d, $J=23.7 \mathrm{~Hz}, 2 \mathrm{C}), 68.3$ (1C), 54.3 (1C), 49.2 (1C), 33.6 (1C), 26.2 (1C), 24.6 (2C), 24.4 (1C), 24.3 (1C), 23.2 (2C). IR ( $\mathrm{KBr}$ film) $\left(\mathrm{cm}^{-1}\right) \vee 3194,3084,2924,2853,1796,1657,1631,1575$, 1480, 1450, 1377, 1241, 1154, 1098, 1044, 980, 856, 799, 744, 462. $\mathrm{MS}(\mathrm{ESI}+) 408.2[\mathrm{M}+\mathrm{H}]$.

3-((R)-2'-Hydroxy-1,1'-binaphthyl-2-ylamino)-4-((1R,2R)-2(piperidin-1-yl)cyclohexylamino)cyclobut-3-ene-1,2-dione (5hg)

Following the general procedure, compound 5 hg was obtained after $88 \mathrm{~h}$ of reaction at room temperature as a yellow solid in $68 \%$ yield. $[\alpha]_{\mathrm{D}}{ }^{24}=+85\left(c 0.44, \mathrm{CHCl}_{3}\right) .{ }^{1} \mathrm{H} \mathrm{NMR}(300 \mathrm{MHz}$, $\left.\mathrm{CDCl}_{3}\right) \delta 8.01(\mathrm{~d}, J=8.8 \mathrm{~Hz}, 1 \mathrm{H}), 7.92-7.79(\mathrm{~m}, 3 \mathrm{H}), 7.62(\mathrm{br}$ $\mathrm{d}, J=6.7 \mathrm{~Hz}, 1 \mathrm{H}), 7.40(\mathrm{dt}, J=1.1,8.0 \mathrm{~Hz}, 1 \mathrm{H}), 7.34-7.11(\mathrm{~m}$, $5 \mathrm{H}), 6.96(\mathrm{~d}, J=8.3 \mathrm{~Hz}, 1 \mathrm{H}), 6.00$ (br s, $2 \mathrm{H}), 3.85$ (br s, $1 \mathrm{H})$, 2.77-2.10 (m, 6H), 1.91-1.51 (m, 3H), 1.49-0.99 (m, $11 \mathrm{H}) .{ }^{13} \mathrm{C}$ APT-NMR (75 MHz, $\left.\mathrm{CDCl}_{3}\right) \delta 184.1$ (1C), 182.1 (1C), 168.4 (1C), 163.8 (1C), 152.7 (1C), 134.5 (1C), 133.5 (1C), 133.4 (1C), 131.53 (1C), 130.7 (1C), 130.1 (1C), 129.0 (2C), 128.2 (2C), 127.4 (1C), 127.1 (1C), 125.7 (1C), 125.5 (1C), 124.1 (1C), 123.5 (1C), 120.7 (1C), 118.8 (1C), 113.2 (1C), 67.9 (1C), 54.2 (1C), 49.5 (2C), 34.8 (1C), 25.2 (1C), 24.9 (1C), 24.2 (2C), $23.8(1 \mathrm{C}), 23.2(1 \mathrm{C})$. IR ( $\mathrm{KBr}$ film) $\left(\mathrm{cm}^{-1}\right)$ v 3251, 
2924, 2854, 1792, 1683, 1595, 1505, 1463, 1377, 1338, 1261, 1095, 1021, 801. MS (ESI+) 546.3 [M+H] .

3-((R)-2'-Hydroxy-1,1'-binaphthyl-2-ylamino)-4-((1R,2R)-2(pyrrolidin-1-yl)cyclohexylamino)cyclobut-3-ene-1,2-dione (5hh)

Following the general procedure, compound $\mathbf{5 h h}$ was obtained after $92 \mathrm{~h}$ of reaction at room temperature as a yellow solid in $50 \%$ yield. $[\alpha]_{\mathrm{D}}{ }^{24}=+227\left(c 0.48, \mathrm{CHCl}_{3}\right) .{ }^{1} \mathrm{H}$ NMR $(400 \mathrm{MHz}$, $\left.\mathrm{CDCl}_{3}\right) 7.96(\mathrm{~d}, J=8.8 \mathrm{~Hz}, 1 \mathrm{H}), 7.89(\mathrm{~d}, J=8.1 \mathrm{~Hz}, 1 \mathrm{H}), 7.81$ (app. dd, $J=6.7,7.5 \mathrm{~Hz}, 2 \mathrm{H}), 7.70-7.53(\mathrm{~m}, 1 \mathrm{H}), 7.40$ (t, $J=$ $7.4 \mathrm{~Hz}, 1 \mathrm{H}), 7.33-7.09(\mathrm{~m}, 5 \mathrm{H}), 6.94(\mathrm{~d}, J=8.4 \mathrm{~Hz}, 1 \mathrm{H}), 6.32$ (br s, 2H), 3.72 (br s, 1H), 2.75-2.45 (m, 4H), 2.12-1.87 (m, $1 \mathrm{H}), 1.80-1.40(\mathrm{~m}, 4 \mathrm{H}), 1.39-0.73(\mathrm{~m}, 9 \mathrm{H}) .{ }^{13} \mathrm{C}$ APT-NMR $\left(100 \mathrm{MHz}, \mathrm{CDCl}_{3}\right) \delta 183.7$ (1C), 181.9 (1C), 168.5 (1C), 164.8 (1C), 153.1 (1C), 134.5 (1C), 133.6 (1C), 133.3 (1C), 131.5 (1C), 130.4 (1C), 129.5 (1C), 128.8 (2C), 128.2 (1C), 128.1 (1C), 127.1 (1C), 126.9 (1C), 125.9 (1C), 125.5 (1C), 124.2 (1C), 123.3 (1C), 121.7 (1C), 119.2 (1C), 114.1 (1C), 63.1 (1C), 55.8 (1C), 48.0 (2C), 34.3 (1C), 29.7 (1C), 24.2 (1C), 24.0 (1C), 23.5 (2C). IR ( $\mathrm{KBr}$ film) $\left(\mathrm{cm}^{-1}\right)$ v 3240, 2924, 2854, 1792, 1683, 1596, 1505, 1462, 1428, 1377, 1336, 1271, 815, 748. MS (ESI+) $532.3[\mathrm{M}+\mathrm{H}]$.

\section{Acknowledgements}

We thank the Lilly Company for the concession of the Spanish Lilly Prize 2012 to R. P. Herrera, which has allowed this research. J.V.A.-R. thanks the DGA Government for a predoctoral fellowship. We also thank Prof. M. Concepción Gimeno (ISQCH) for her help and encouragement in our research.

\section{Notes and references}

${ }^{a}$ Laboratorio de Organocatálisis Asimétrica, Departamento de Química Orgánica. Instituto de Síntesis Química y Catálisis Homogénea (ISQCH). CSIC-Universidad de Zaragoza. E-50009 Zaragoza, Spain Phone: +34 976761190. E-mail: raquelph@unizar.es

Electronic Supplementary Information (ESI) available: General experimental information, ${ }^{1} \mathrm{H}$ and ${ }^{13} \mathrm{C}$ NMR spectra for all new squaramides 5. See DOI: 10.1039/b000000x/

1 a) G. H. Posner, Chem. Rev., 1986, 86, 831; b) P. A. Dalby, G. J. Lye and J. M. Woodley in Handbook of Chiral Chemicals (Ed.: D. Ager), CRC, Boca Raton, 2005, pp. 419-428; c) C. Vaxelaire, P. Winter and M. Christmann, Angew. Chem. Int. Ed., 2011, 50, 3605; d) Ł. Albrecht, H. Jiang and K. A. Jørgensen, Angew. Chem. Int. Ed., 2011, 50, 8492; and references therein cited. For some interesting examples, see also: e) A. Saha, R. B. N. Baig, J. Leazer and R. S. Varma, Chem. Commun., 2012, 48, 8889; f) R. B. N. Baig and R. S. Varma, Green Chem., 2012, 14, 625; g) R. B. N. Baig, M. N. Nadagouda and R. S. Varma, Green Chem., 2014, 16, 2122.

2 A. M. Walji and D. W. C. MacMillan, Synlett, 2007, 1477.
3 For pivotal reviews in this area of research, see: a) J. Alemán, A. Parra, H. Jiang and K. A. Jørgensen, Chem. Eur. J., 2011, 17, 6890; b) R. I. Storer, C. Aciro and L. H. Jones, Chem. Soc. Rev., 2011, 40, 2330; c) F. R. Wurm and H.-A. Klok, Chem. Soc. Rev., 2013, 42, 8220 ; d) J. V. Alegre-Requena, Synlett, 2014, 298. For selected examples, see: e) P. Sejwal, Y. Han, A. Shah and Y.-Y. Luk, Org. Lett., 2007, 9, 4897; f) Ł. Albrecht, G. Dickmeiss, C. F. Weise, C. Rodríguez-Escrich and K. A. Jørgensen, Angew. Chem. Int. Ed., 2012, 51, 13109; g) K. S. Yang, A. E. Nibbs, Y. E. Türkmen and V. H. Rawal, J. Am. Chem. Soc., 2013, 135, 16050; h) J. V. AlegreRequena, E. Marqués-López, P. J. Sanz Miguel and R. P. Herrera, Org. Biomol. Chem., 2014, 12, 1258.

4 J. P. Malerich, K. Hagihara and V. H. Rawal, J. Am. Chem. Soc., 2008, 130, 14416.

5 a) B. M. Trost, Science, 1991, 254, 1471; b) B. M. Trost, Acc. Chem. Res., 2002, 35, 695.

6 E. Maqués-López, J. V. Alegre-Requena and R. P. Herrera, European Pat. EP14382260.9 filed Jul. 07, 2014.

7 C. Reichardt and T. Welton in Solvents and Solvent Effects in Organic Chemistry, Fourth Edition. (Ed.: C. Reichardt), Wiley-VCH Verlag GmbH \& Co. KGaA, Weinheim, 2003.

8 S. Cohen and S. G. Cohen, J. Am. Chem. Soc., 1966, 88, 1533.

9 H. Konishi, T. Y. Lam, J. P. Malerich and V. H. Rawal, Org. Lett., 2010, 12, 2028.

10 For the preparation of the opposite enantiomer, see: W. Yang and D.M. Du, Adv. Synth. Catal., 2011, 353, 1241.

11 Y. Zhu, J. P. Malerich and V. H. Rawal, Angew. Chem. Int. Ed., 2010, 49, 153.

12 W. Yang and D.-M. Du, Org. Lett., 2010, 12, 5450.

13 H. Jiang, M. W. Paixão, D. Monge and K. A. Jørgensen, J. Am. Chem. Soc., 2010, 132, 2775.

14 For the second step (40\% yield), see: R. Baran, E. Veverková, A. Škvorcová and R. Šebesta, Org. Biomol. Chem., 2013, 11, 7705. The authors did not detail the yield of the first step, we thus took the yield of the first step showed in Rawal's work (85\% yield) (ref. 4).

15 For the preparation of the opposite enantiomer, see: W. Yang and D.M. Du, Org. Biomol. Chem., 2012, 10, 6876.

16 F. Olmo, C. Rotger, I. Ramírez-Macías, L. Martínez, C. Marín, L. Carreras, K. Urbanová, M. Vega, G. Chaves-Lemaur, A. Sampedro, M. J. Rosales, M. Sánchez-Moreno and A. Costa, J. Med. Chem., 2014, 57, 987.

17 a) P. M. M. Guedes, G. K. Silva, F. R. S. Gutierrez and J. S. Silva, Expert Rev. Anti-Infect. Ther., 2011, 9, 609; b) J. A. Urbina, Acta Trop., 2010, 115, 55; c) H. Cerecetto and M. González, Pharmaceuticals, 2010, 3, 810.

18 M. J. Coghlan, W. A. Carroll and M. Gopalakrishnan, J. Med. Chem., 2001, 44, 1627.

19 F. M. Ashcroft and F. M. Gribble, Trends Neurosci., 1998, 21, 288.

20 For the pioneering syntheses, see: a) J. A. Butera and S. A. Antane US Pat. 5,506,252 filed Oct. 2, 1994 and issued Ap. 9, 1996; b) J. A. Butera, M. M. Antane, S. A. Antane, T. M. Argentieri, C. Freeden, R. F. Graceffa, B. H. Hirth, D. Jenkins, J. R. Lennox, E. Matelan, N. W. Norton, D. Quagliato, J. H. Sheldon, W. Spinelli, D. Warga, A. Wojdan and M. Woods, J. Med. Chem., 2000, 43, 1187.

21 For selected studies using WAY-133537 (14), see: a) A. Wojdan, C. Freeden, M. Woods, G. Oshiro, W. Spinelli, T. J. Colatsky, J. H. 
Sheldon, N. W. Norton, D. Wargan, M. M. Antane, S. A. Antane, J. A. Butera and T. M. Argentieri, J. Pharmacol. Exp. Therap., 1999, 289, 1410; b) S. A. Buckner, I. Milicic, A. V. Daza, M. J. Coghlan and M. Gopalakrishnan, Brit. J. Pharmacol., 2002, 135, 639; c) A. C. Fabiyi, M. Gopalakrishnan, J. J. Lynch III, J. D. Brioni, M. J. Coghlan and M. E. Brune, BJU International, 2003, 91, 284; d) J. A. Butera, D. J. Jenkins, J. R. Lennox, J. H. Sheldon, N. W. Norton, D. Warga and T. M. Argentieri, Bioorg. Med. Chem. Lett., 2005, 15, 2495; e) R. J. Altenbach, M. E. Brune, S. A. Buckner, M. J. Coghlan, A. V. Daza, A. Fabiyi, M. Gopalakrishnan, R. F. Henry, A. Khilevich, M. E. Kort, I. Milicic, V. E. Scott, J. C. Smith, K. L. Whiteaker and W. A. Carroll, J. Med. Chem., 2006, 49, 6869.

22 For selected studies using WAY-151616 (18), see: a) M. M. Antane, D. R. Herbst, G. R. McFarlane, E. G. Gundersen, B. H. Hirth, D. A. Quagliato, R. F. Graceffa, J. A. Butera and A. M. Gilbert, Interanational Pat. WO 98/02413 filed Jul. 16, 1997 and issued Jun. 22, 1998; b) M. J. Gast and T. R. Koziol, Interanational Pat. WO 98/11888 filed Sept. 17, 1997 and issued Mar. 26, 1998; c) J. A. Butera and T. M. Argentieri, Drugs Fut., 2000, 25, 239; d) J.-N. Mahy Gehenne, M. J. Rodriguez Allue and M. Pugliese, Interanational Pat. WO 2006/000607 filed Jun. 23, 2005 and issued Jan. 5, 2006.

23 a) D. R. Herbst, M. M. Antane, G. R. McFarlane, E. G. Gundersen, B. H. Hirth, D. A. Quagliato, R. F. Graceffa, J. A. Butera, US Pat. 5,763,474 filed Jul. 7, 1997 and issued Jun. 9, 1998; b) A. M. Gilbert, M. M. Antane, T. M. Argentieri, J. A. Butera, G. D. Francisco, C. Freeden, E. G. Gundersen, R. F. Graceffa, D. Herbst, B. H. Hirth, J. R. Lennox, G. McFarlane, N. W. Norton, D. Quagliato, J. H. Sheldon, D. Warga, A. Wojdan and M. Woods, J. Med. Chem., 2000, 43, 1203. 